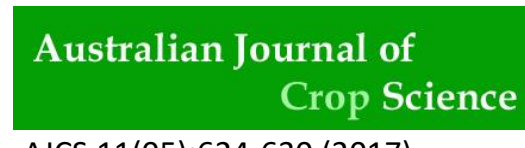

AJCS 11(05):624-630 (2017)

doi: 10.21475/ajcs.17.11.05.p578

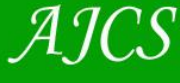

ISSN:1835-2707

\title{
Effect of chitosan on physiology, photosynthesis and biomass of rice (Oryza sativa L.) under elevated ozone
}

\author{
Rutairat Phothi*, Chonlada Dechakiatkrai Theerakarunwong \\ Faculty of Science and Technology, Nakhon Sawan Rajabhat University, Nakhon Sawan 60000, Thailand
}

*Corresponding author:rutairat_p@hotmail.com

\begin{abstract}
This research aimed to study the effects of chitosan on physiology, photosynthesis and biomass of rice cultivar RD47 under elevated ozone. Rice samples were grown at indoor climate controlled chambers, allowing the inlet air to pass through charcoal filters. For combined effects of chitosan and ozone, rice was soaked and sprayed with chitosan $0.05 \%$ (W/V) under elevated ozone concentration at $40 \mathrm{ppb}\left(\mathrm{Chi}+\mathrm{EO}_{3} 40\right)$ and $70 \mathrm{ppb}\left(\mathrm{Chi}+\mathrm{EO}_{3} 70\right)$. Control groups $(\mathrm{CF})$ with no additional ozone were also studied. Samples were analyzed weekly for tiller number per plants, leaf area, leaf chlorophyll, photosynthesis, shoot biomass, root biomass and total biomass. The results obviously showed that ozone at the concentration of both 40 and $70 \mathrm{ppb}$ caused negative effects on rice physiology, photosynthesis and biomass. The $70 \mathrm{ppb}$ concentration, particularly, caused sever damage. Whilst soaking and spraying with chitosan could significantly reduce the harmful effects of ozone compared with the control group. For the samples soaked and sprayed with chitosan under elevated ozone for 21 days, $\mathrm{Chi}+\mathrm{EO}_{3} 40$ and $\mathrm{Chi}+\mathrm{EO}_{3} 70$ significantly performed more photosynthesis and contained more leaf chlorophyll than $\mathrm{EO}_{3} 40$ and $\mathrm{EO}_{3} 70$, respectively $(\mathrm{p} \leq 0.05)$. In addition, chitosan could reduce the ozone negative effects and increased higher physiology and photosynthesis rate. However, there was no significant difference in biomass compared with the control group. Even through, ozone has been gradually increasing which made plants at risk, chitosan treatment could significantly ameliorate the effect of ozone and serve as a plant growth promoter with no harmful to human being.
\end{abstract}

Key words: ozone, chitosan, rice, photosynthesis, chlorophyll, biomass.

Abbreviations: $\mathrm{CF}$ _charcoal-filter, $\mathrm{EO}_{3} 40 \_$elevated ozone concentration at $40 \mathrm{ppb}, \mathrm{EO}_{3} 70 \_$elevated ozone concentration at $70 \mathrm{ppb}$, Chi_chitosan $0.05 \%$ w/v, $\mathrm{Chi}+\mathrm{EO}_{3} 40$ _ chitosan $0.05 \%$ w/v combine with elevated ozone concentration at $40 \mathrm{ppb}, \mathrm{Chi}_{+} \mathrm{EO}_{3} 70$ _ chitosan $0.05 \% \mathrm{w} / \mathrm{v}$ combine with elevated ozone concentration at $70 \mathrm{ppb}$

\section{Introduction}

Plant growth is facing formidable challenges in meeting the rising of global problem due to extended droughts, flood, increasing temperature or environmental pollutions. Air pollution is one of the major factor impacts on either plant growth or plant production. All these constraints are caused by human activities from the use of insecticides and herbicides, which inevitably lead to the release of organic and inorganic contaminants into the agricultural products and affect human-health. Especially, tropospheric ozone $\left(\mathrm{O}_{3}\right)$ has been recognized as a major threat to global agriculture.

Nowadays, the concentration of ozone has continuously been increasing over the standard limit in many areas. Thailand is an agricultural country and the major rice exporter in the world market. An increase in tropospheric ozone has been reported in 25 provinces. The value of average ozone concentration reported from monitoring station of Pollution Control Department was higher than the standard limit. The maximum 1 hour average was $125 \mathrm{ppb}$ (average 1 hour standards $=100 \mathrm{ppb}$ ), and the maximum 8 hour average was about $97 \mathrm{ppb}$ (average 8 hour standards $=$ $70 \mathrm{ppb}$ ) (Pollution Control Department, 2015). It is predicted from IPCC that the ozone intensity in 2050 will increase to 60-100 ppb (IPCC, 2007).

Ozone concentration has been increasing around the world due to industrial revolution which released ozone reactants such as nitrogen dioxide and volatile organic compounds
(Vainonen and KangasjëRvi, 2015). Typically, ozone causes damage to plants by penetration to stomata. After ozone gas is taken up by plants, it becomes reactive with oxygen species (ROS) i.e. $\mathrm{O}_{2}^{-}, \mathrm{HO}^{-}$and $\mathrm{H}_{2} \mathrm{O}_{2}$ (Umponstira et al., 2006) and causes leaf injury (Felzer et al., 2007), leaf senescence, reduces chlorophyll contents, plant metabolism, growth and physiological processes in different ways (Al-Rawahy et al., 2013). Ozone inhibits carbon dioxide fixation in carboxylation pathway and reduces quantities and efficiency of rubisco enzymes in Calvin cycle (Vainonen and Kangasjärvi, 2015). Therefore, it decreases photosynthesis and affects plant growth (Phothi et al., 2016), as well as reduces leaf area and productivity (Sarkar and Agrawal, 2012; Noormets et al., 2010)

Enhancing plant strength using chitosan plays an important role in inhibition of ozone damage. Chitosan is a natural amino polysaccharide polymer produced from chitin. The direct alteration of plant physiology at optimum chitosan concentration increases photosynthetic efficiency, nutrient uptake, crop production and decreases plant stress and disinfection (Van et al., 2013). Moreover, chitosan could mineralize organic nutrients into inorganic forms, which is easily absorbed by plant roots (Boonlertnirun et al., 2006; Sun et al., 2008). The enhanced performance of plant production is attributed to chitosan, which serves as non-toxic and biodegradable plant growth promoter (Salachna and 
Zawaddzińska, 2014; Farouk et al., 2013; Boonlertnirun et al., 2006; Boonlertnirun et al., 2008).

This research studied the effects of chitosan on plant growth under the elevated ozone. Influence of chitosan has been observed as beneficial on photosynthesis and biomass of rice. Knowledge about climate change and human health concerns together has been applied to develop cropping area. There are many reports studied on effects of severe drought, ozone and temperature in relation to both biotic and abiotic stresses on crops. However, there is little known about the advantages of chitosan application or other natural substances with no toxic to environment on ozon amelioration. Thus this research can be of importance for development of food security through the climate change in the future.

\section{Results and Discussion}

\section{The effect of chitosan on the number and area of leaves under elevated ozone}

From the results, the number of leaves was decreased due to treatment with ozone; however, it was increased after chitosan treatment. The effect of ozone was drastically decreased, when combined with chitosan and elevated ozone at concentration of 40 and $70 \mathrm{ppb}$. The ameliorative effects of chitosan could be especially observed under $40 \mathrm{ppb}$ of ozone concentration. This tendency was observed compared to the control group (Table 1). These results were similar to earlier study on plant tillers of rice conducted by Mondal et al. (2012). Regarding the increasing of photosynthesis by chitosan, carbon metabolism was significantly increased, which affected cell redox homeostasis (Chamnamanoontham et al., 2015).

In addition, leaf area is one of the factors that play an important role in photochemical reaction and carbon fixation, which affects plant growth and biomass. Many researches have revealed that ozone has significant effect on the leaf area. The similar result was obtained in this work, whilst, soaking and spraying of rice by chitosan could reduce the effect of ozone. The concentration of $40 \mathrm{ppb}$ ozone, which is common in Thailand showed significant effects when compared with the control group. It is predicted that the concentration of ozone in the near future would climb up to $70 \mathrm{ppb}$ and expected to damage both number of leaf and leaf area.

\section{The effect of chitosan under the elevated ozone on chlorophyll content of rice}

Short term effect experiment (7 Days of $\mathrm{O}_{3}$ exposure) without chitosan showed the reduction of chlorophyll content under the concentration of ozone at $70 \mathrm{ppb}$, when compared to the control group. The sample treated with chitosan (40 and 70 ppb) after ozone exposure for 7 days presented the similar level of chlorophyll to that of the control group. This showed that chitosan has decreased the effect of ozone due to the nitrogen compounds in chitosan, which has enhanced the chlorophyll synthesis. After 14 and 21 days of ozone fumigation, all treatments showed the lower levels of leaf chlorophyll under the concentration of ozone at $70 \mathrm{ppb}$. The value had statistical significance for the combined chitosan with $\mathrm{EO}_{3} 70$ (Table 2). This indicated that chitosan play an important role on the increase of rice production under the elevated ozone. Several publications reported that the reduction of chlorophyll caused by ozone is the key to affect photosynthesis rate in photochemical reactions (Sarkar and Agrawal, 2012).

\section{The effect of chitosan on photosynthesis rate of rice under elevated ozone}

The photosynthesis rate of rice was decreased under the elevated ozone concentration of 40 and $70 \mathrm{ppb}\left(\mathrm{EO}_{3} 40\right.$ and $\mathrm{EO}_{3} 70$ ), compared to the control group (CF), whereas the photosynthesis was increased by treating with chitosan. When chitosan with elevated ozone were combined, the photosynthesis increased due to the sensitive response of rice to chitosan, while ozone penetrated to stomata and created reactive oxygen species (ROS), further affecting photosynthetic cells, resulting in the cellular component injury, like proteins, nucleic acids and membrane lipids (Katiyar et al., 2015). Moreover, ozone could reduce stomatal conductance, inhibit carbon dioxide fixation in carboxylation process and reduce the quantities and efficiency of rubisco enzymes in Calvin cycle (Ainsworth et al., 2012). The oligochitosan could increase antioxidants i.e. Superoxide dismutase (SOD) and Catalases (CAT) (Guo et al., 2003), Guaiacol peroxidase (POX) activities (Ma et al., 2014) in leaves and the photosynthetic cells, when they were affected by ozone. In the same trend, chitosan had a positive effect on factors associated with photosynthesis and chlorophyll content (Mondal et al., 2013; Theerakarunwong and Phothi, 2016). In this study, we showed that the photosynthesis of rice was decreased under the elevated ozone concentration at $70 \mathrm{ppb}\left(\mathrm{EO}_{3} 70\right)$. The efficiency values were $15.30,10.37$ and $8.24 \mu \mathrm{mol} \mathrm{m} \mathrm{s}^{-1}$ on days $7^{\text {th }}, 14^{\text {th }}$ and $21^{\text {st }}$, respectively. The maximum photosynthesis of leaf was found only under chitosan exposure $\left(27.65,25.07\right.$ and $26.40 \mu \mathrm{mol} \mathrm{m} \mathrm{m}^{-2} \mathrm{~s}^{-1}$, respectively). In this study the combinational effects of Chi+ $+\mathrm{EO}_{3} 40$ and $\mathrm{Chi}+\mathrm{EO}_{3} 70$ was found that the elevated ozone at $40 \mathrm{ppb}$ in combination with chitosan reduced the damage caused by ozone. Under Chi+ $+\mathrm{EO}_{3} 40$, the photosynthesis was significantly higher than in the sample treated under $\mathrm{EO}_{3} 40$ (Fig. 1). Moreover, the presence of chitosan helped to increase the positive effect of ozone on photosynthesis which showed no difference compared to the control group (Table 3). As the same trend, the photosynthesis rate under $\mathrm{Chi}+\mathrm{EO}_{3} 70$ was higher than the sample treated with $\mathrm{EO}_{3} 70$ by $28.76 \%$ after day 21 . Similar result was reported that rice showed the decrease of photosynthesis in Bangladesh rice, Indian rice and wheat after exposure to elevated ozone (Akhtar, et al., 2010; Sarkar and Agrawal, 2012; Sarkar and Agrawal, 2010). Also, the combined effects of elevated ozone and chitosan, studied by Zhao et al. (2010), could suppress the toxic effects of ozone to soybean as it ameliorated ozone-related oxidative damage and protected anti-oxidative system from ozone stress.

\section{The effect of chitosan on biomass under elevated ozone}

Biomass of rice is a necessary trait to investigate the effect of chitosan on photosynthesis. In this study, the total biomass (shoot, root and total biomass) was increased when compared with the control group (Fig. 2). The combination of $\mathrm{Chi}+\mathrm{EO}_{3} 40$ and $\mathrm{Chi}+\mathrm{EO}_{3} 70$ helped to reduce the harmful 
Table 1. Tiller number per plants and leaf area of rice. Plant samples were fumigated by ozone and soaked + sprayed with chitosan $0.05 \% \mathrm{w} / \mathrm{v}$ for 21 days; charcoal-filter $(\mathrm{CF})$, ozone $40 \mathrm{ppb}\left(\mathrm{EO}_{3} 40\right)$, ozone $70 \mathrm{ppb}\left(\mathrm{EO}_{3} 70\right)$, chitosan $0.05 \% \mathrm{w} / \mathrm{v}$ (Chi), chitosan $0.05 \% \mathrm{w} / \mathrm{v}$ combine with ozone $40 \mathrm{ppb}\left(\mathrm{Chi}+\mathrm{EO}_{3} 40\right)$, chitosan $0.05 \% \mathrm{w} / \mathrm{v}$ combine with ozone $40 \mathrm{ppb}\left(\mathrm{Chi}+\mathrm{EO}_{3} 40\right)$. The data represent the mean \pm SE. Different letters indicate significant differences among treatments at $\mathrm{p} \leq 0.05$.

\begin{tabular}{|c|c|c|c|}
\hline Treatments & $\begin{array}{c}7 \text { Days of } \\
\text { exposure } \mathrm{O}_{3}\end{array}$ & $\begin{array}{l}14 \text { Days of } \\
\text { exposure } \mathrm{O}_{3}\end{array}$ & $\begin{array}{l}21 \text { Days of } \\
\text { exposure } \mathrm{O}_{3}\end{array}$ \\
\hline \multicolumn{4}{|c|}{ Tiller number per plants } \\
\hline $\mathrm{CF}$ & $30.40 \pm 1.80 \mathrm{bc}$ & $36.40 \pm 1.63 \mathrm{ab}$ & $40.80 \pm 2.22 \mathrm{a}$ \\
\hline $\mathrm{EO}_{3} 40$ & $25.80 \pm 1.83 \mathrm{c}$ & $28.80 \pm 3.83 b c$ & $32.00 \pm 3.42 b$ \\
\hline $\mathrm{EO}_{3} 70$ & $24.80 \pm 1.56 \mathrm{c}$ & $18.40 \pm 2.29 \mathrm{c}$ & $16.00 \pm 1.82 \mathrm{c}$ \\
\hline Chi & $37.60 \pm 3.14 \mathrm{a}$ & $41.00 \pm 3.24 \mathrm{a}$ & $44.20 \pm 2.58 \mathrm{a}$ \\
\hline $\mathrm{Chi}+\mathrm{EO}_{3} 40$ & $37.80 \pm 2.56 \mathrm{a}$ & $41.60 \pm 6.22 \mathrm{a}$ & $47.00 \pm 3.19 a$ \\
\hline $\mathrm{Chi}+\mathrm{EO}_{3} 70$ & $36.80 \pm 1.88 \mathrm{ab}$ & $36.00 \pm 2.89 \mathrm{ab}$ & $32.40 \pm 2.38 b$ \\
\hline \multicolumn{4}{|l|}{ Leaf area } \\
\hline $\mathrm{CF}$ & $23.23 \pm 1.68 b$ & $28.14 \pm 2.17 b$ & $33.98 \pm 1.09 \mathrm{~b}$ \\
\hline $\mathrm{EO}_{3} 40$ & $17.10 \pm 1.47 \mathrm{c}$ & $18.93 \pm 2.19 \mathrm{~cd}$ & $24.13 \pm 0.73 d$ \\
\hline $\mathrm{EO}_{3} 70$ & $13.87 \pm 1.39 \mathrm{c}$ & $14.77 \pm 0.32 \mathrm{~d}$ & $14.15 \pm 1.50 \mathrm{e}$ \\
\hline Chi & $28.78 \pm 1.12 \mathrm{a}$ & $35.42 \pm 1.24 \mathrm{a}$ & $39.97 \pm 0.84 \mathrm{a}$ \\
\hline $\mathrm{Chi}+\mathrm{EO}_{3} 40$ & $24.11 \pm 0.55 b$ & $28.03 \pm 0.78 b$ & $27.62 \pm 1.06 \mathrm{c}$ \\
\hline $\mathrm{Chi}+\mathrm{EO}_{3} 70$ & $24.37 \pm 0.82 b$ & $22.47 \pm 1.24 \mathrm{c}$ & $16.17 \pm 1.48 \mathrm{e}$ \\
\hline
\end{tabular}
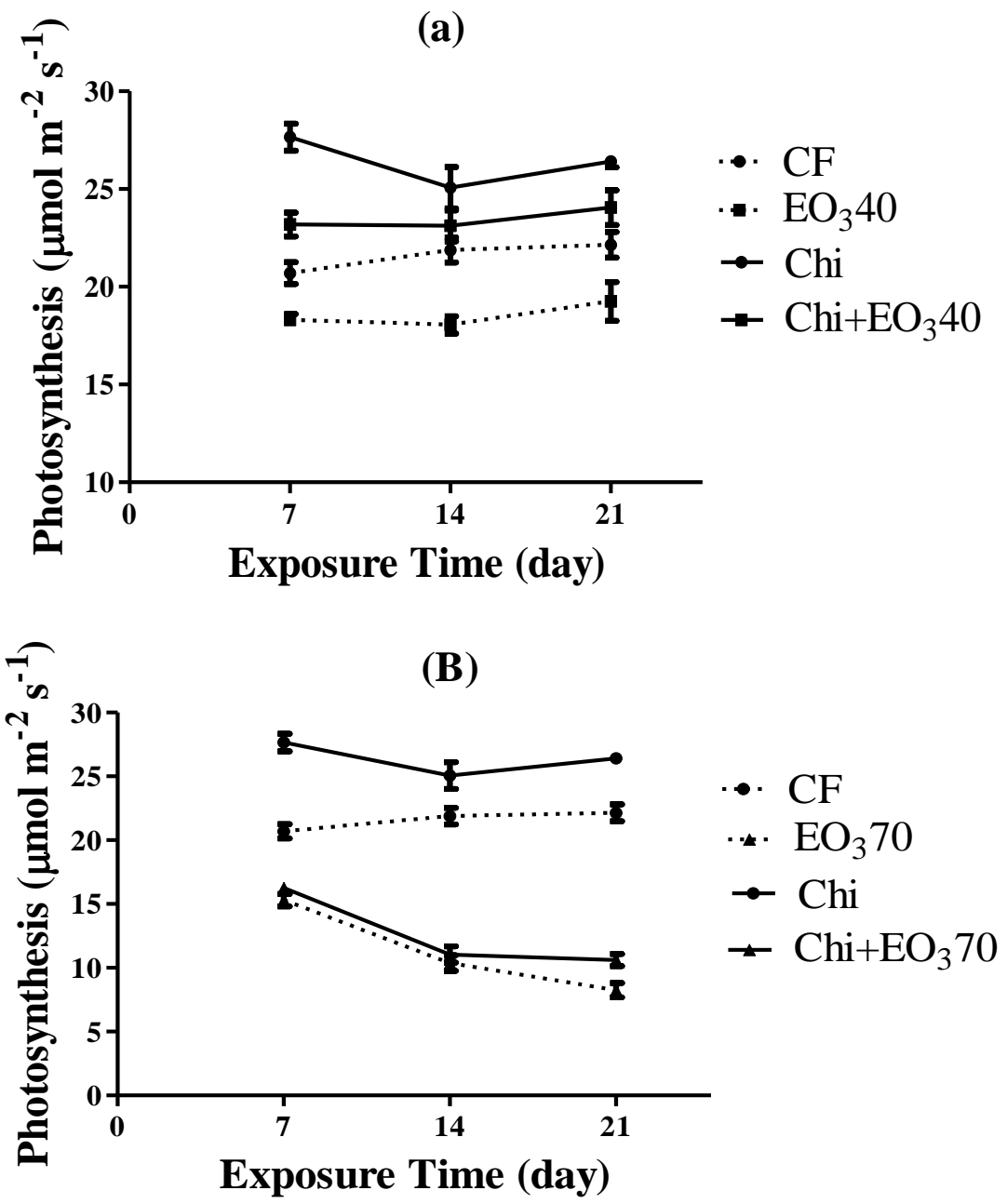

Fig 1 .The photosynthesis of rice (RD 47) in control (CF) ozone $40 \mathrm{ppb}\left(\mathrm{EO}_{3} 40\right)$ chitosan. (Chi) no chitosan with ozone treated 40 $\mathrm{ppb}\left(\mathrm{Chi}+\mathrm{EO}_{3} 40\right)$ (a) and the photosynthesis of $\mathrm{RD} 47$ in control (CF) ozone 70 ppb $\left(\mathrm{EO}_{3} 70\right)$ chitosan (Chi) no chitosan with ozone treated $70 \mathrm{ppb}\left(\mathrm{Chi}+\mathrm{EO}_{3} 70\right)(\mathrm{b})$ 
Table 2. Leaf chlorophyll of rice (SPAD unit). Plant samples were fumigated by ozone and soaked + sprayed with chitosan $0.05 \%$ w/v for 21 days; charcoal-filter $(\mathrm{CF})$, ozone $40 \mathrm{ppb}\left(\mathrm{EO}_{3} 40\right)$, ozone $70 \mathrm{ppb}\left(\mathrm{EO}_{3} 70\right)$, chitosan $0.05 \% \mathrm{w} / \mathrm{v}(\mathrm{Chi})$, chitosan $0.05 \% \mathrm{w} / \mathrm{v}$ combine with ozone $40 \mathrm{ppb}\left(\mathrm{Chi}+\mathrm{EO}_{3} 40\right)$, chitosan $0.05 \% \mathrm{w} / \mathrm{v}$ combine with ozone $40 \mathrm{ppb}\left(\mathrm{Chi}_{+} \mathrm{EO}_{3} 40\right)$. The data represent the mean \pm SE. Different letters indicate significant differences among treatments at $p \leq 0.05$.

\begin{tabular}{lccc}
\hline Treatments & $\begin{array}{c}7 \text { Days of } \\
\text { exposure } \mathrm{O}^{\mathbf{3}}\end{array}$ & $\begin{array}{c}14 \text { Days of } \\
\text { exposure } \mathrm{O}^{\mathbf{3}}\end{array}$ & $\begin{array}{c}21 \text { Days of } \\
\text { exposure } \mathrm{O}^{\mathbf{3}}\end{array}$ \\
\hline $\mathrm{CF}$ & $42.24 \pm 0.78 \mathrm{a}$ & $41.40 \pm 1.00 \mathrm{~b}$ & $40.44 \pm 1.14 \mathrm{~b}$ \\
$\mathrm{EO}_{3} 40$ & $42.16 \pm 0.12 \mathrm{a}$ & $40.42 \pm 0.81 \mathrm{~b}$ & $39.90 \pm 0.66 \mathrm{~b}$ \\
$\mathrm{EO}_{3} 70$ & $24.66 \pm 2.43 \mathrm{~b}$ & $23.44 \pm 0.93 \mathrm{~d}$ & $23.70 \pm 1.42 \mathrm{~d}$ \\
$\mathrm{Chi}$ & $43.74 \pm 0.65 \mathrm{a}$ & $44.54 \pm 0.65 \mathrm{a}$ & $44.00 \pm 0.74 \mathrm{a}$ \\
$\mathrm{Chi}+\mathrm{EO}_{3} 40$ & $42.22 \pm 0.85 \mathrm{a}$ & $42.38 \pm 0.57 \mathrm{ab}$ & $40.70 \pm 0.33 \mathrm{~b}$ \\
$\mathrm{Chi}+\mathrm{EO}_{3} 70$ & $41.52 \pm 0.87 \mathrm{a}$ & $30.72 \pm 1.35 \mathrm{c}$ & $31.18 \pm 1.33 \mathrm{c}$ \\
\hline
\end{tabular}

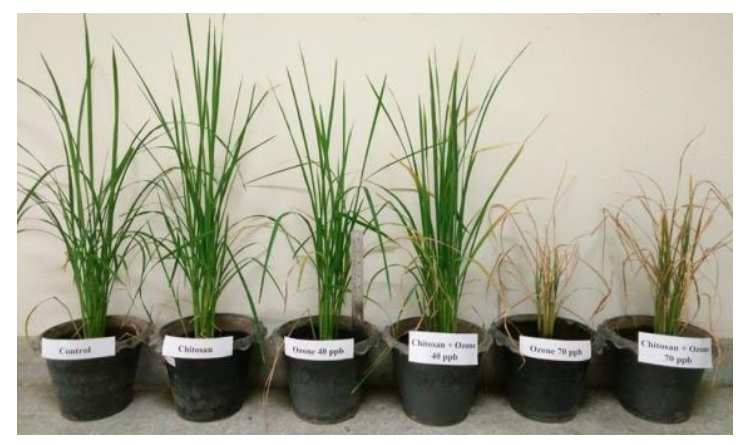

Fig 2. The RD47 cultivar after fumigation day 21 as: control (CF) chitosan (Chi) ozone $40 \mathrm{ppb}\left(\mathrm{EO}_{3} 40\right)$. combined chitosan and ozone $40 \mathrm{ppb}\left(\mathrm{Chi}+\mathrm{EO}_{3} 40\right)$ ozone $70 \mathrm{ppb}\left(\mathrm{EO}_{3} 70\right)$ and combined chitosan and ozone $\mathbf{7 0} \mathrm{ppb}\left(\mathrm{Chi}+\mathrm{EO}_{3} 70\right)$

Table 3. Photosynthesis rate of rice. Plant samples were fumigated by ozone and soaked + sprayed with chitosan $0.05 \% \mathrm{w} / \mathrm{v}$ for 21 days; charcoal-filter $(\mathrm{CF})$, ozone $40 \mathrm{ppb}\left(\mathrm{EO}_{3} 40\right)$, ozone $70 \mathrm{ppb}\left(\mathrm{EO}_{3} 70\right)$, chitosan $0.05 \% \mathrm{w} / \mathrm{v}$ (Chi), chitosan $0.05 \%$ w/v combine with ozone $40 \mathrm{ppb}\left(\mathrm{Chi}+\mathrm{EO}_{3} 40\right)$, chitosan $0.05 \% \mathrm{w} / \mathrm{v}$ combine with ozone $40 \mathrm{ppb}\left(\mathrm{Chi}+\mathrm{EO}_{3} 40\right)$. The data represent the mean $\pm \mathrm{SE}$. Different letters indicate significant differences among treatments at $\mathrm{p} \leq 0.05$.

\begin{tabular}{lccc}
\hline Treatment & $\begin{array}{c}7 \text { Days of } \\
\text { exposure } \mathrm{O}^{3}\end{array}$ & $\begin{array}{c}14 \text { Days of } \\
\text { exposure } \mathrm{O}^{3}\end{array}$ & $\begin{array}{c}21 \text { Days of } \\
\text { exposure } \mathrm{O}^{3}\end{array}$ \\
\hline $\mathrm{CF}$ & $20.70 \pm 0.56 \mathrm{c}$ & $21.88 \pm 0.64 \mathrm{~b}$ & $22.15 \pm 0.66 \mathrm{~b}$ \\
$\mathrm{EO}_{3} 40$ & $18.32 \pm 0.29 \mathrm{~d}$ & $18.05 \pm 0.44 \mathrm{c}$ & $19.25 \pm 0.98 \mathrm{c}$ \\
$\mathrm{EO}_{3} 70$ & $15.30 \pm 0.49 \mathrm{e}$ & $10.37 \pm 0.62 \mathrm{~d}$ & $8.24 \pm 0.57 \mathrm{e}$ \\
$\mathrm{Chi}$ & $27.65 \pm 0.69 \mathrm{a}$ & $25.07 \pm 1.06 \mathrm{a}$ & $26.40 \pm 0.28 \mathrm{a}$ \\
$\mathrm{Chi}+\mathrm{EO}_{3} 40$ & $23.18 \pm 0.61 \mathrm{~b}$ & $23.12 \pm 0.79 \mathrm{ab}$ & $24.05 \pm 0.89 \mathrm{~b}$ \\
$\mathrm{Chi}+\mathrm{EO}_{3} 70$ & $16.27 \pm 0.40 \mathrm{e}$ & $11.04 \pm 0.64 \mathrm{~d}$ & $10.61 \pm 0.47 \mathrm{~d}$ \\
\hline
\end{tabular}

Table 4. Shoot, root and total biomass of rice. Plant samples were fumigated by ozone and soaked + sprayed with chitosan $0.05 \%$ $\mathrm{w} / \mathrm{v}$ for 21 days; charcoal-filter $(\mathrm{CF})$, ozone $40 \mathrm{ppb}\left(\mathrm{EO}_{3} 40\right)$, ozone $70 \mathrm{ppb}\left(\mathrm{EO}_{3} 70\right)$, chitosan $0.05 \% \mathrm{w} / \mathrm{v}(\mathrm{Chi})$, chitosan $0.05 \% \mathrm{w} / \mathrm{v}$ combine with ozone $40 \mathrm{ppb}\left(\mathrm{Chi}+\mathrm{EO}_{3} 40\right)$, chitosan $0.05 \% \mathrm{w} / \mathrm{v}$ combine with ozone $40 \mathrm{ppb}\left(\mathrm{Chi}_{+} \mathrm{EO}_{3} 40\right)$. The data represent the mean \pm SE. Different letters indicate significant differences among treatments at $p \leq 0.05$.

\begin{tabular}{llll}
\hline Treatment & $\begin{array}{l}7 \text { Days of } \\
\text { exposure } \mathrm{O}^{3}\end{array}$ & $\begin{array}{l}14 \text { Days of } \\
\text { exposure } \mathrm{O}^{3}\end{array}$ & $\begin{array}{l}21 \text { Days of } \\
\text { exposure } \mathrm{O}^{3}\end{array}$ \\
\hline Shoot & & & \\
\hline $\mathrm{CF}$ & $1.01 \pm 0.08 \mathrm{c}$ & $2.51 \pm 0.56 \mathrm{bc}$ & $4.62 \pm 0.22 \mathrm{~b}$ \\
$\mathrm{EO}_{3} 40$ & $0.60 \pm 0.08 \mathrm{~d}$ & $1.02 \pm 0.13 \mathrm{de}$ & $3.74 \pm 0.26 \mathrm{c}$ \\
$\mathrm{EO}_{3} 70$ & $0.35 \pm 0.05 \mathrm{~d}$ & $0.71 \pm 0.93 \mathrm{e}$ & $1.69 \pm 0.16 \mathrm{c}$ \\
$\mathrm{Chi}$ & $2.85 \pm 0.14 \mathrm{a}$ & $3.93 \pm 0.18 \mathrm{a}$ & $5.84 \pm 0.33 \mathrm{a}$ \\
$\mathrm{Chi}+\mathrm{EO}_{3} 40$ & $2.05 \pm 0.22 \mathrm{~b}$ & $3.24 \pm 0.34 \mathrm{ab}$ & $4.53 \pm 0.35 \mathrm{~b}$ \\
$\mathrm{Chi}+\mathrm{EO}_{3} 70$ & $1.01 \pm 0.09 \mathrm{c}$ & $1.93 \pm 0.42 \mathrm{~cd}$ & $2.98 \pm 0.06 \mathrm{c}$ \\
\hline $\mathrm{Root}$ & & & \\
\hline $\mathrm{CF}$ & $0.27 \pm 0.05 \mathrm{c}$ & $2.04 \pm 0.06 \mathrm{~b}$ \\
$\mathrm{EO}$ & $0.25 \pm 0.07 \mathrm{~d}$ & $1.38 \pm 0.30 \mathrm{a}$ & $1.22 \pm 0.11 \mathrm{c}$ \\
$\mathrm{EO} 30$ & $0.15 \pm 0.01 \mathrm{~d}$ & $0.42 \pm 0.13 \mathrm{bc}$ & $0.96 \pm 0.06 \mathrm{c}$ \\
$\mathrm{Chi}$ & $1.62 \pm 0.23 \mathrm{a}$ & $0.16 \pm 0.33 \mathrm{c}$ & $2.68 \pm 0.28 \mathrm{a}$ \\
$\mathrm{Chi}+\mathrm{EO}_{3} 40$ & $0.85 \pm 0.10 \mathrm{~b}$ & $2.10 \pm 0.23 \mathrm{a}$ & $2.04 \pm 0.06 \mathrm{~b}$ \\
$\mathrm{Chi}+\mathrm{EO}_{3} 70$ & $0.29 \pm 0.02 \mathrm{c}$ & $1.56 \pm 0.16 \mathrm{a}$ & \\
\hline $\mathrm{Total}$ & & $1.22 \pm 0.57 \mathrm{ab}$ & \\
\hline $\mathrm{CF}$ & $1.29 \pm 0.09 \mathrm{c}$ & & $6.66 \pm 0.28 \mathrm{~b}$ \\
$\mathrm{EO}_{3} 40$ & $0.85 \pm 0.08 \mathrm{~cd}$ & $3.89 \pm 0.81 \mathrm{~b}$ & $4.97 \pm 0.15 \mathrm{c}$ \\
$\mathrm{EO}_{3} 70$ & $0.50 \pm 0.04 \mathrm{~d}$ & $1.45 \pm 0.23 \mathrm{~cd}$ & $2.66 \pm 0.21 \mathrm{~d}$ \\
$\mathrm{Chi}$ & $4.46 \pm 0.35 \mathrm{a}$ & $0.87 \pm 0.96 \mathrm{~d}$ & $8.52 \pm 0.43 \mathrm{a}$ \\
$\mathrm{Chi}+\mathrm{EO}_{3} 40$ & $2.90 \pm 0.29 \mathrm{~b}$ & $6.03 \pm 0.33 \mathrm{a}$ & $6.57 \pm 0.33 \mathrm{~b}$ \\
$\mathrm{Chi}+\mathrm{EO}_{3} 70$ & $1.30 \pm 0.11 \mathrm{c}$ & $4.80 \pm 0.82 \mathrm{ab}$ & $4.29 \pm 0.24 \mathrm{c}$ \\
\hline
\end{tabular}


effects of ozone. The values of biomass from shoot, root and total biomass were equivalent to $4.53,2.04$ and $6.57 \mathrm{~g}$ under $\mathrm{Chi}+\mathrm{EO}_{3} 40$ on day 21. Under $\mathrm{EO}_{3} 40$, the values of the biomass of stem, root and total biomass were 3.74, 1.22 and $4.97 \mathrm{~g}$, respectively (Table 4), which were higher than those in the $\mathrm{EO}_{3} 40(21.13 \%, 67.21 \%$ and $32.19 \%$, respectively) condition. In addition, under $\mathrm{EO}_{3} 70$, the values of the biomass of shoot, root and total biomass were 1.69, 0.96 and $2.66 \mathrm{~g}$, respectively. Similarly, the combination of $\mathrm{Chi}+\mathrm{EO}_{3} 70$ helped to reduce the effect of elevated ozone, whilst they were significantly higher than the sample under $\mathrm{EO}_{3} 70$. Imai and Kobori (2008) found that shoot, root and total biomass yields of rice were decreased by elevated ozone that suppressed photosynthesis. Rice was considered as another sensitive crop, similar to wheat, which showed reduction of biomass even when exposed to mild ozone concentration at $40 \mathrm{ppb}$ (Feng et al., 2008). Results demonstrated that seed soaking and spraying by chitosan stimulated growth and induced plant immune system either to water stresses. Similar result was revealed that chitosan could reduce the effect of water stress in cowpea (Farouk and Ramadan Amany, 2012) sweet pepper (Ghoname et al., 2010) and rice (Boonlertnirun et al., 2006). In addition, chitosan had a positive effect to regulate the immune system of plant under abiotic stress as well as to increase the excretion of resistant enzymes (Boonlertnirun et al., 2008). This could explain that the application of chitosan through seed soaking and spraying has produced antioxidants to protect against the effects of ROS under stress condition. The photosynthesis in rice increased due to enhanced stomatal conductance and transpiration rate (Khan et al., 2002). Furthermore, chitosan contained phosphorous which was necessary for biosynthesis and translocation of carbohydrates during stimulating cell division and forming DNA and RNA. Again, chitosan could enhance nitrogen and potassium in leaf, which is related to the number of chloroplasts per cell, cell size and number per unit area. Consequently, it increased chlorophyll which improved the rate of photosynthesis and biomass.

\section{Materials and Methods}

\section{Plant materials}

In this study, Thai rice cultivar RD47 provided by Phitsanulok Rice Research Center was selected due to its good quality and scent. Rice seeds were germinated in $21 \mathrm{x}$ $26 \mathrm{~cm}$ plastic tray for 14 days. Rice samples were divided into 2 different treatments: soaked in chitosan solution (chitosan $0.05 \% \mathrm{~W} / \mathrm{V}$ ) and water (control group). Seedlings were then transferred to 8 inch pot filled with clay soil for 14 days. For chitosan treatment, plant samples were sprayed with chitosan solution and water as normal. For the control group, plant samples were treated with fertilizer and water. All treatments were then transferred into new environmental control chambers which were kept for a week prior to 21 days of ozone treatment.

\section{Experimental facility}

The experiment was conducted in indoor climate control chambers, in which inlet air passed through charcoal-filters to eliminate ambient ozone before entering the chambers. The facility was located at Air Pollution Laboratory, Faculty of Agriculture, Natural Resources and Environment, Naresuan University, Phitsanulok, Thailand.

\section{Preparation of chitosan solution}

In brief, a series of medium molecular weight $(50 \mathrm{kDa})$ chitosan solution $(0.05 \% \mathrm{w} / \mathrm{v})$ were prepared by dissolving $0.05 \mathrm{~g}$ in $100 \mathrm{~mL} 0.05 \% \mathrm{w} / \mathrm{v}$ acetic acid solution.

\section{Chitosan and ozone exposure and climatic control chambers}

Rice samples were divided into 2 main groups: (1) seedling that soaked and sprayed with chitosan $0.05 \%$ (2) the control group (water sprayed); before they delivered to ozone fumigation chambers at the concentrations of 40 and $70 \mathrm{ppb}$.

The experiment was arranged as $2 \times 3$ factorials. Two treatments were applied. Plant samples were sprayed with chitosan $0.05 \%$ and also water (control). Three doses of ozone were applied in a Completely Randomized Design (CRD) $(2 \times 3$ factorials $)$. Ozone in indoor climate control chambers was set to typically background level $(<10 \mathrm{ppb})$ by passing inlet air from outside through charcoal filter prior to enter to the chambers. These chambers were allocated in to 3 different treatment as the control group (CF; Charcoal-Filter: no additional ozone), elevated ozone concentration at $40 \mathrm{ppb}$, elevated ozone concentration at $70 \mathrm{ppb}$. The experimental groups were allocated as:

CF: Charcoal-Filter: no additional chitosan and ozone.

$\mathrm{EO}_{3} 40$ : Elevated ozone concentration at $40 \mathrm{ppb}$.

$\mathrm{EO}_{3} 70$ : Elevated ozone concentration at $70 \mathrm{ppb}$.

Chi: Soaked and sprayed with $0.05 \%$ chitosan without additional ozone.

Chi $+\mathrm{EO}_{3} 40$ : Soaked and sprayed with $0.05 \%$ chitosan + elevated ozone concentration of $40 \mathrm{ppb}$.

$\mathrm{Chi}+\mathrm{EO}_{3} 70$ : Soaked and sprayed with $0.05 \%$ chitosan + elevated ozone concentration of $70 \mathrm{ppb}$.

Amounts of ozone were generated by an ozone generator model OZ 3020 (Belle, Ltd., Thailand). Ozone levels were daily monitored by an ozone analyzer model 49C (Thermo Environmental Instruments, USA). Temperature was controlled at $35^{\circ} \mathrm{C}$ and $28{ }^{\circ} \mathrm{C}$ during day and night in the air conditioning room. Relative humidity was maintained in a range of $80-90 \%$ by Testo $608-\mathrm{H} 1$-Thermohygrometer (Testo Limited, UK). Light was supplied for 12 hours day ${ }^{-1}$ by two $400 \mathrm{~W}$ metal-halide bulbs which provided $600 \mu \mathrm{mol} \mathrm{m} \mathrm{m}^{-2} \mathrm{~s}^{-1}$ of photosynthetic photon flux density (PPFD).

\section{Measurements of photosynthesis, leaf chlorophyll, total soluble sugar and biomass}

Leaf number, leaf area, leaf chlorophyll (SPAD) and photosynthesis were analyzed once a week at day 7,14 and 21 during ozone exposure. Photosynthesis was analyzed by a portable photosynthesis system (LI- 6400, LiCor, Lincoln, NE, USA) as an open system with logged carbon dioxide concentration of $400 \mu \mathrm{mol} \mathrm{mol}^{-1}$ in the leaf chamber and a constant air flow rate of $500 \mu \mathrm{mol} \mathrm{s}{ }^{-1}$. The photosynthetic photon flux density (PPFD) was maintained at $1500 \mu \mathrm{mol} \mathrm{m}$ $\mathrm{s}^{-1}$ by an artificial light source (Shimono et al., 2004).

Leaf chlorophyll was measured by chlorophyll meter (SPAD) (SPAD-502, Soil and Plant Analysis Development), Minolta Camera Co., Osaka, Japan).

Shoot and root of plant samples were finally harvested, washed and then subsequently dried in a hot air oven at $70^{\circ} \mathrm{C}$ for 72 hours before weighing. 


\section{Statistical analysis}

The data were analyzed by analysis of variance (ANOVA) and differences between groups were tested by Duncan's New Multiple Range Test (DMRT) at $p \leq 0.05$.

\section{Conclusion}

This study mainly focused on investigating the effect of chitosan under abiotic stress by elevated ozone concentration of 40 and $70 \mathrm{ppb}$. The results indicated that numbers of tiller, leaf area, chlorophyll, photosynthesis and biomass of rice were decreased. Thus, ozone is recognized as an obstacle for food security. For chitosan treatment, 21 days of seed soaking and spraying with chitosan solution could improve plant immune system under stress conditions. Numbers of tiller, leaf area, chlorophyll, photosynthesis and biomass of rice were increased compared with the control group. The reason is that chitosan may act as a carbon source for antioxidant production as well as photosynthesis acceleration. Such knowledge can be of importance for improving plant species and development of food security through the climate change. While chitosan is a natural biodegradable polymer, it is nontoxic to human and livestock. Thus, there is possibility of chitosan application at large scale for mass production of plants.

\section{Acknowledgement}

The authors would like to thank Research and Develop Institute, Nakhonsawan Rajabhat University for the financial support. Special thanks are extended to Faculty of Science and Technology, Nakhon Sawan Rajabhat University and Faculty of Agricultural, Natural Resources and Environment, Naresuan University for facilities and equipments.

\section{References}

Ainsworth EA, Yendrek CR, Sitch S, Collins WJ, Emberson LD (2012) The Effects of Tropospheric Ozone on Net Primary Productivity and Implications for Climate Change. Annu Rev Plant Biol. 63(1): 637-661.

Akhtar N, Yamaguchi M, Inada H, Hoshino D, Kondo T, Fukami M, Funada R, Izuta T (2010) Effects of ozone on growth, yield and leaf gas exchange rates of four Bangladeshi cultivars of rice (Oryza sativa L.). Environ Pollut. 158(9): 2970-2976.

Al-Rawahy SH, Sulaiman H, Farooq SA, Karam MF, Sherwani N (2013) Effect of $\mathrm{O}_{3}$ and $\mathrm{CO}_{2}$ Levels on Growth, Biochemical and Nutrient Parameters of Alfalfa (Medicago Sativa). APCBEE Proc. 5: 288-295.

Boonlertnirun S, Boonraung C, Suvanasara R (2008) Application of chitosan in rice production. J Met Mater Miner. 18(2): 47-52.

Boonlertnirun S, Sarobol E, Sooksathan I (2006) Effect of molecular weight of chitosan on yield potential of rice cultivar Suphan Buri 1. Kasetsart J (Nat. Sci). 40: 854-861.

Chamnanmanoontham N, Pongprayoon W, Pichayangkura R, Roytrakul S, Chadchawan S (2015) Chitosan enhances rice seedling growth via gene expression network between nucleus and chloroplast. Plant Growth Regul. 75:101-114.

Farouk S, Ramadan AA, Showler AT (2013) Chitosan effects on physiochemical indicators of drought-induced leaf stress in cowpea. Plant Knowl J. 2(4): 135-144.

Felzer BS, Cronin T, Reilly JM, Melillo JM, Wang X (2007) Impacts of ozone on trees and crops. CR Geosci. 339 (1112): $784-798$.
Feng Z, Kobayashi K, Ainsworth EA (2008) Impact of elevated ozone concentration on growth, physiology, and yield of wheat (Triticum aestivum L.): A meta-analysis. Global Change Biol. 14(11): 2696-2708.

Ghoname AA, El-Nemr MA, Abdel-Mawgoud AMR, ElTohamy WA (2010) Enhancement of sweet pepper crop growth and production by application of biological, organic and nutritional solutions. Res J Agric Biol Sci. 6(3): 349355.

Guo HL, Du YG, Bai XF, Zhao XM (2003) Effects of active oxygen on suspended cotton cell culture by oligochitosan. Chin J Mar Drugs. 1: 11-12.

Imai K, Kobori K (2008) Effects of the interaction between ozone and carbon dioxide on gas exchange, ascorbic acid content, and visible leaf symptoms in rice leaves. Photosynthetica. 46(3): 387-394.

IPCC. 2007. Climate Change (2007) The Physical Science Basis. Contribution of Working Group I to the Fourth Assessment Report of the Intergovernmental Panel on Climate Change. In Solomon S, Qin D, Manning M, Chen Z, Marquis M, Averyt KB, Tignor M, Miller HL (ed.) Climate Change 2007: The Physical Science Basis. Contribution of Working Group I to the Fourth Assessment Report of the Intergovernmental Panel on Climate Change. Cambridge University Press, Cambridge. United Kingdom and New York, USA.

Katiyar D, Hemantaranjan A, Singh B (2015) Chitosan as a promising natural compound to enhance potential physiological responses in plant: a review. Indian J Plant Physi. 20(1): 1-9.

Khan WM, Prithiviraj B, Smiyh DL (2002) Effect of foliar application of chitin oligo-saccharides on photosynthesis of maize and soybean. Photosynthetica. 40: 621-624.

Ma LJ, Li YY, Wang LL, Li XM, Liu T, Bu N (2014) Germination and physiological response of wheat (Triticum aestivum) to presoaking with oligochitosan. Int $\mathrm{J}$ Agric Biol. 16: 766-770.

Mondal MMA, Malek MA, Puteh AB, Ismail MR, Ashrafuzzaman M, Naher L (2012) Effect of foliar application of chitosan on growth and yield in okra. Austral J Crop Sci. 6(5): 918-921.

Mondal MMA, Malek MA, Puteh AB, Ismail MR (2013) Foliar application of chitosan on growth and yield attributes of mung bean (Vigna radiata (L.) Wilczek). Bangl J Bot. 42(1): 179-183.

Noormets A, Kull O, Sôber A, Kubiske ME, Karnosky DF (2010) Elevated $\mathrm{CO}_{2}$ response of photosynthesis depends on ozone concentration in aspen. Environ Pollut. 158(4): 992-999.

Phothi R, Umponstira C, Sarin C, Siriwong W, Nabheerong $\mathrm{N}$ (2016) Combining effects of ozone and carbon dioxide application on photosynthesis of Thai jasmine rice (Oryza sativa L.) cultivar Khao Dawk Mali 105. Aust J Crop Sci. 10(4): 591-597.

Pollution Control Department (2015) Thailand State of Pollution Report 2015. Ministry of Natural Resources and Environment. Bangkok, Thailand.

Salachna P, Zawadzińska A (2014) Effect of chitosan on plant growth, flowering and corms yield of potted freesia. J Ecologi Eng. 15(3): 97-102.

Sarkar A, Agrawal SB (2010) Elevated ozone and two modern wheat cultivars: An assessment of dose dependent sensitivity with respect to growth, reproductive and yield parameters. Environ Exp Bot. 69(3): 328-337.

Sarkar A, Agrawal SB (2012) Evaluating the response of two high yielding Indian rice cultivars against ambient and 
elevated levels of ozone by using open top chambers. J Environ Manage. 95: S19-S24.

Shimono H, Hasegawa T, Fujimura S, Iwama K (2004) Responses of leaf photosynthesis and plant water status in rice to low water temperature at different growth stages. Field Crop Res. 89(1): 71-83.

Sun T, Yao Q, Zhou DX, Mao F (2008) Antioxidant activity of N-carboxymethyl chitosan oligosaccharides. Bioorg med chem lett. 18(21): 5774-5776.

Theerakarunwong DC, Phothi R (2016) Physiological and photosynthesis enhancement of Thai rice (Oryza sativa $\mathrm{L}$.) cultivars by biochitosan. NU Int J Sci. 13 (1): $37-49$.

Vainonen JP, Kangasjärvi J (2015) Plant signalling in acute ozone exposure. Plant Cell Environ. 38(2): 240-252.
Van SN, Minh HD, Anh DN (2013) Study on chitosan nanoparticles on biophysical characteristics and growth of Robusca coffee in green house. Biocatal Agr Biotec. 289294.

Umponstira C, Pimpa W, Nanegrungsun S (2006) Physiological and biochemical responses of cowpea (Vigna unguiculata (L.) Walp) to ozone. Songklanakarin J Sci Technol. 28(4): 861-869.

Zhao TH, Wang JL, Wang Y, Sun JW, Cao Y (2010) Effects of Reactive Oxygen Species Metabolic System on Soybean (Glycine max) Under Exogenous Chitosan to Ozone Stress. Bull Environ Contam Toxicol. 85(1): 59-63. 